\title{
Effects of Drying Temperature and Relative Humidity on Quality Properties of Chinese Dried Noodles
}

\author{
Ying-Quan Zhang $\mathbb{D D}^{1,2}$ Ying Hui, ${ }^{1,2}$ Yuan Wang, ${ }^{2}$ Bo Zhang, ${ }^{2}$ Bo-Li Guo, ${ }^{2}$ \\ Guo-Quan Zhang $\mathbb{D}^{1}$, and Yi-Min $\mathrm{Wei}^{2}$ \\ ${ }^{1}$ College of Food Science and Engineering, Northwest A\&F University, Yangling 712100, Shaanxi, China \\ ${ }^{2}$ Institute of Food Science and Technology, Chinese Academy of Agricultural Sciences, Beijing 100193, China \\ Correspondence should be addressed to Ying-Quan Zhang; zhangyingquan821@126.com and Guo-Quan Zhang; zhanggq98@ \\ 126.com
}

Received 24 September 2020; Revised 8 December 2020; Accepted 19 December 2020; Published 31 December 2020

Academic Editor: wujun Ma

Copyright (c) 2020 Ying-Quan Zhang et al. This is an open access article distributed under the Creative Commons Attribution License, which permits unrestricted use, distribution, and reproduction in any medium, provided the original work is properly cited.

\begin{abstract}
The influence of the drying conditions on protein structural properties and its impact on Chinese dried noodles (CDN) quality properties is addressed in this study. The CDN were produced under nine different drying conditions utilizing combination of three temperatures $\left(40^{\circ} \mathrm{C}, 60^{\circ} \mathrm{C}\right.$, and $\left.80^{\circ} \mathrm{C}\right)$ and three relative humidities $(65 \%, 75 \%$, and $85 \%)$. The color, texture profile analysis of uncooked and cooked noodles, shrinkage ratio, and cooking quality of CDN were assessed. SEM and FTIR microimaging were investigated to determine the changes in the gluten structural properties. Drying temperature and relative humidity have significant effects on quality characteristics of CDN. However, the influences on different indicators were different. Drying temperature was the main influencing factor of the quality of $\mathrm{CDN}$ and protein microstructure. After the drying temperature exceeded $60^{\circ} \mathrm{C}$, proteins began to aggregate, and the surface protein distribution became uneven. Compared with cross section, the uniformity of protein distribution on the surface of noodles showed a significant decrease. A high temperature $\left(60^{\circ} \mathrm{C}\right)$ could improve the quality of CDN products. The quality of CDN products could be adjusted by the combination of drying temperature and relative humidity.
\end{abstract}

\section{Introduction}

Chinese dried noodles (CDN) are one of the most popular noodle types all over the world due to their convenience, variety, long shelf life, and nutritional values. The total production yield of $\mathrm{CDN}$ has reached over 8 million tons per year in China, which consumes about 35\% of the total flour consumption in mainland China $[1,2]$. Drying process is a key step of CDN production. The process design and parameter control largely determine the quality of product, production efficiency, and energy consumption [3].

Temperature and relative humidity (RH) in drying chamber are the two main conditions during drying process. A reasonable drying temperature can promote the evaporation of moisture in noodles, improve the quality of noodles, shorten drying time, and reduce production costs
[4]. At present, the manufacturers generally use the low- or medium-temperature (lower than $45^{\circ} \mathrm{C}$ ) drying process relying on air heating (coal or gas), while the drying condition regulation and control are mainly based on personal experiences [3]. The effects of drying conditions and process on the quality of spaghetti and dried udon noodles have been extensively explored [5-13]. Inazu et al. found that the effect of relative humidity on the apparent moisture diffusivity of Japanese noodle (udon) was smaller than that of temperature, but its impact could not be neglected [6]. Mercier et al. reviewed 66 studies on enriched pasta and showed that high drying temperatures generally improve the cooking properties of enriched pasta [10]. Padalino et al. suggested that spaghetti cooking quality was positively affected by drying temperature increase and found that the improvement of sensory and cooking quality properties of spaghetti was 
directly related to the density increase in both chemical crosslink of protein matrix and physical crosslink of starch granules [11]. Bruneel et al. implied that an optimal degree of protein polymerization during drying and/or the subsequent cooking led to the high-quality pasta [14]. Verbauwhede et al. studied the impact of heat on microstructure of heating nonfermented dough and found out that the gluten microstructure was affected from $65^{\circ} \mathrm{C}$ onwards [15]. Wang et al. observed that gluten content mainly affected the drying rate in the middle drying period of Chinese dried noodle [16]. The effects of drying parameters on moisture content, moisture state, or energy consumption have been researched $[3,17]$. However, the effect of drying temperature, relative humidity, and their interactions on quality characteristics of Chinese dried noodles, the changes in protein microstructure under different drying conditions, and the influences of these changes on the quality characteristics of CDN products were rarely explored.

The aims of this study were to investigate the effects of various drying temperatures and different relative humidity on the color, cooking, and texture characteristics of CDN, explore the changes in protein microstructure, and reveal the correlation among these parameters and product quality.

\section{Materials and Methods}

2.1. Materials. The wheat variety Ningchun 4 was used in this the experiment, which is a good noodle wheat variety. Ningchun 4 is a hard spring type, with low protein and wet gluten contents $(12.3 \%$ and $28.5 \%)$ and medium to strong gluten strength $(6.6 \mathrm{~min}$ of stability time and $206 \mathrm{BU}$ of resistance). The flour was produced in the MLU 202 experimental flour mill (Bühler, Switzerland) with the flour yield of $71.2 \%$. The edible salt used in the noodles was from the local supermarket. Other reagents used were of analytical grade.

2.2. Preparation of Fresh Noodles. Ningchun 4 flour (14\% wet weight) of $1000 \mathrm{~g}$ was mixed with $350 \mathrm{~g}$ distilled water and $1 \%$ edible salt for $8 \mathrm{~min}$ in a dough mixer (Henan Dongfang Food Machinery Equipment Co., Ltd., China) to make dough crumbs. The obtained dough crumbs were rolled twice on the MT5-215 sheet rolling machine (Nanjing Yangzi Cereals, Oils and Food Machinery Co., Ltd., China) to obtain a $4 \mathrm{~mm}$ thick noodle sheet, which was put into ziplock bags, sealed, and rested at room temperature for $30 \mathrm{~min}$. Thereafter, the dough sheet was then rolled four times to obtain a $1 \mathrm{~mm}$ thick sheet, which was then cut into $2 \mathrm{~mm}$ wide wet raw noodles.

2.3. Drying Conditions Design. The fresh noodles were hung in a drying chamber (BLC-250-III, Beijing Land and Technology co., Ltd., Beijing, China) which had been equilibrated in advance. The drying parameters including temperature and relative humidity were set to $40,60,80^{\circ} \mathrm{C}$, and $65 \%, 75 \%, 85 \%$, respectively. In the present work, nine different combinations of drying conditions were implemented. The drying temperature and relative humidity were adjusted to different combinations before operations. Drying time was $300 \mathrm{~min}$. After drying, the noodles were cut into a length of $25 \mathrm{~cm}$ and put into ziplock bags for subsequent use.

2.4. Color of Dried Noodles. Twenty noodle sticks were randomly selected and then measured at five positions on each noodle stick for the colors using the DigiEye DigitalImaging System (VeriVide Limited, UK). In total, 100 measurements were obtained for each sample and the average value was calculated as the color of dried noodle samples. According to the CIE Lab system, three color indexes of $\mathrm{L}^{*}, \mathrm{a}^{*}$, and $\mathrm{b}^{*}$ were obtained. Each sample was tested for three times.

2.5. Noodle Shrinkage Ratio. Firstly, ten straight dried noodle sticks were randomly selected. Then, the width and thickness in the middle and two ends $(2 \mathrm{~cm}$ away from the ends) of selected noodles were measured with a vernier caliper. With the width $\left(a_{0}, 2 \mathrm{~mm}\right)$ and thickness $\left(b_{0}, 1 \mathrm{~mm}\right)$ of wet raw noodles as the standard, the shrinkage ratio $(\psi)$ of dried noodles was calculated as follows:

$$
\begin{aligned}
\psi(\%) & =\left(S_{0}-S_{1}\right) \times \frac{100}{S_{0}}, \\
S_{0} & =a_{0} \times b_{0}, \\
S_{1} & =a \times b,
\end{aligned}
$$

where $S_{0}$ is the cross-sectional area of the wet noodle, $\mathrm{mm}^{2}$, $S_{1}$ is the cross-sectional area of the dried noodle, $\mathrm{mm}^{2}, a_{0}$ is the width of the wet raw noodle, mm, $b_{0}$ is the thickness of the wet raw noodle, mm, $a$ is the width of the dried noodle, $\mathrm{mm}$, and $b$ is the thickness of the dried noodle, mm.

2.6. Texture Characteristics of Uncooked CDNs. Twenty noodle sticks were randomly selected from each batch of $\mathrm{CDN}$ product and then cut into the length of $18 \mathrm{~cm}$. The TAXT plus Texture Analyzer (Stable Micro System, UK) was used to measure the bending resistance of dried noodles. The A/SFR probe dropped at a speed of $1.00 \mathrm{~mm} / \mathrm{s}$ until the noodle stick was broken. The maximum resistance encountered during the process when the probe pressed the noodle represented the bending strength of the dried noodle. The distance from the point where the probe was in contact with the noodle to the point where the noodle was broken indicated the breaking distance. The area of the region surrounded by the force and time in the period from contacting time between the noodle and the probe to breaking time was considered breaking work.

2.7. Water Absorption Rate (WAR) and Cooking Loss Ratio (CLR). According to AACCI 66-50.001 [18] with minor modifications, $20 \mathrm{CDN}$ sticks were placed into $500 \mathrm{~mL}$ of boiling distilled water. When the white core disappeared, heat was removed, and the time was recorded as the optimal cooking time (OCT) of the CDN. In a separate test, $10.00 \mathrm{~g}$ of 
noodles was weighed, and $500 \mathrm{~mL}$ of distilled water was added in a stainless-steel pot and heated to the boiling point with an induction cooker. The weighed sample was added into the pot and the boiling state was maintained. After OCT was reached, noodles were obtained from the pot immediately. When no obvious water could be observed on the noodle surface, the noodles were weighed to calculate water absorption ratio (WAR, \%). The remaining noodle soup in the steel pot was heated until all liquid had evaporated. The stainless-steel pot was put in an oven and baked at $105^{\circ} \mathrm{C}$ to constant weight. The total mass of the stainless-steel pot and the remaining material was weighed to calculate the cooking loss ratio (CLR, \%).

2.8. Texture Characteristics of Cooked CDNs. According to the method described by Liu et al. [19], twenty noodles were randomly selected, cooked for optimal cooking time, fished out immediately, rinsed with tap water for $30 \mathrm{~s}$. A set of five sticks were placed in parallel on the loading platform in a TA. XT plus Texture Analyzer (Stable Micro System, UK). Testing parameters were set as follows: TPA measurement mode; the probe, A/LKB-F; the speed before the measurement, $2 \mathrm{~mm} / \mathrm{s}$; the measurement speed, $0.8 \mathrm{~mm} / \mathrm{s}$; the speed after the measurement, $2 \mathrm{~mm} / \mathrm{s}$; the compression ratio, $70 \%$; the interval between two compressions, $10 \mathrm{~s}$; the starting induction force, initial value, $10 \mathrm{~g}$; and the data acquisition rate, $200 \mathrm{pps}$. Three parallel experiments were performed for each sample.

2.9. Scanning Electron Microscopy (SEM). The CDN samples were cut, then respectively fixed with glutaraldehyde for $48 \mathrm{~h}$ and osmic acid for $2 \mathrm{~h}$, and dried at the supercritical point of $\mathrm{CO}_{2}$. The dried samples were then cut off with pliers. The cut samples with a flat surface were selected and fixed on the sample platform. Gold particles were sprayed on the samples with the Hitachi IB-5 Ion Coating Apparatus, and the samples were then placed under a SU 8010 scanning electron microscope (HITACHI, Japan) at 300× and $800 \times$ magnification, observed, and photographed.

2.10. Infrared Microscopic Imaging Analysis. The surface and cross section of the dried noodles were examined by a LUMOS stand-alone FTIR microscope (Bruker, Saarbrucken, Germany) to analyze the protein content distribution on the surface and cross section of noodles. The measurement parameters are as follows: ATR mode, MCT detector, wavenumber range $\left(4000-600 \mathrm{~cm}^{-1}\right)$, air as the reference, the infrared spectral resolution $\left(4 \mathrm{~cm}^{-1}\right)$, and 16 scans. Area array sampling was performed in $15 \times 15$ points (imaging area, $375 \mu \mathrm{m} \times 300 \mu \mathrm{m}$; spatial resolution, $25 \mu \mathrm{m} \times 25 \mu \mathrm{m})$. The air background was automatically removed from the sample spectra in the OPUS 8.1 software. The peaks in the amide I and amide II regions $\left(1715-1484 \mathrm{~cm}^{-1}\right)$ were integrated to generate a $2 \mathrm{D}$ pseudocolor plot, which was used to represent the protein distribution in noodle samples $[20,21]$. The bright purple and red in the scale indicate a high value of protein content while blue indicates a low value.

2.11. Statistical Analysis. All the experiments were repeated at least 3 times and experimental data was expressed as the mean \pm SD. Statistical analysis was carried out by SPSS for Windows version 18.0 (SPSS Inc., Chicago, IL, USA). Oneway analysis of variance (one-way ANOVA) and multiple comparison analysis were carried out to estimate the statistically significant differences between different temperatures, $\mathrm{RH}$, and their combinations, and multiway analysis of variance (multiway ANOVA) was carried out to find out the contributions rate of each factor. Differences were considered to be significant at $P<0.05$.

\section{Results}

\subsection{Quality Properties of Uncooked Noodles}

3.1.1. Color of CDN. The colors of CDN under different drying temperature and relative humidity are shown in Table 1. Under the conditions of different drying temperatures, with the increase in relative humidity, the $\mathrm{L}^{*}$ values of noodles showed the decreasing trend, whereas the $\mathrm{a}^{*}$ values showed the increasing trend. The $\mathrm{L}^{*}$ values combination under the relative humidity of $85 \%$ were significantly lower than those under $65 \%$ and $75 \%$, whereas the $\mathrm{a}^{*}$ values under the relative humidity of $85 \%$ were significantly higher than those under $65 \%$ and $75 \%$. Under the same relative humidity, the $L$ values or $\mathrm{a}^{*}$ values of $\mathrm{CDN}$ under the conditions of different temperatures showed no significant difference $P<0.05$. Under the combination condition of $40^{\circ} \mathrm{C}, 65 \%$, the $\mathrm{b}^{*}$ values were significantly lower than those under other combination conditions $(P<0.05)$. The $\mathrm{b}^{*}$ values under the drying temperature of $60^{\circ} \mathrm{C}$ were significantly lower than those under $80^{\circ} \mathrm{C}$.

3.1.2. Shrinkage Ratio. The shrinkage ratio of CDN showed no regular variation with temperature or relative humidity. Under the combination condition of $40^{\circ} \mathrm{C}$ and $65 \%$, the shrinkage ratio of dried noodles was the lowest, which was significantly lower than that under other combination conditions, while under the combination conditions of $80^{\circ} \mathrm{C}$ and $65 \%$, the shrinkage ratio was the highest (Table 1). There was no significant difference in the shrinkage ratio between other combination conditions of temperature and relative humidity.

3.1.3. TPA of Uncooked CDN. Under the drying temperatures of $40^{\circ} \mathrm{C}$ and $60^{\circ} \mathrm{C}$, with the increase in relative humidity, the bending strength of CDN firstly decreased and then increased. Under the drying temperature of $80^{\circ} \mathrm{C}$, the bending strength showed an increasing trend with increasing humidity. Under the combination condition of $80^{\circ} \mathrm{C}$ and $85 \%$, the bending strength of dried noodles was the highest (Table 2).

Under the drying temperatures of $60^{\circ} \mathrm{C}$ and $80^{\circ} \mathrm{C}$, with the increase in relative humidity, the breaking distance 
TABLE 1: Effects of drying temperature and relative humidity on quality characteristics of uncooked CDN.

\begin{tabular}{cccccc}
\hline \multirow{2}{*}{ Temperature $\left({ }^{\circ} \mathrm{C}\right)$} & Relative humidity $(\%)$ & \multicolumn{2}{c}{ Color of CDN } & Shrinkage ratio (\%) \\
& & $\mathrm{L}^{*}$ & $\mathrm{a}^{*}$ & $12.96 \pm 0.83 \mathrm{c}$ \\
40 & 65 & $89.80 \pm 0.35 \mathrm{ab}$ & $0.41 \pm 0.04 \mathrm{~cd}$ & $13.62 \pm 0.35 \mathrm{~d}$ & $18.17 \pm 1.40 \mathrm{ab}$ \\
& 75 & $89.43 \pm 0.21 \mathrm{bc}$ & $0.61 \pm 0.08 \mathrm{bc}$ & $14.79 \pm 0.23 \mathrm{bc}$ & $16.04 \pm 1.93 \mathrm{~b}$ \\
60 & 85 & $88.78 \pm 0.26 \mathrm{~d}$ & $0.81 \pm 0.10 \mathrm{ab}$ & $14.75 \pm 0.39 \mathrm{bc}$ & $18.20 \pm 1.46 \mathrm{ab}$ \\
& 65 & $89.63 \pm 0.23 \mathrm{ab}$ & $0.41 \pm 0.04 \mathrm{~cd}$ & $14.60 \pm 0.20 \mathrm{c}$ & $17.12 \pm 1.24 \mathrm{~b}$ \\
80 & 75 & $89.63 \pm 0.15 \mathrm{ab}$ & $0.47 \pm 0.07 \mathrm{~cd}$ & $14.61 \pm 0.09 \mathrm{c}$ & $18.40 \pm 1.71 \mathrm{ab}$ \\
& 85 & $88.95 \pm 0.45 \mathrm{~cd}$ & $0.57 \pm 0.02 \mathrm{bc}$ & $14.54 \pm 0.29 \mathrm{c}$ & $20.51 \pm 1.83 \mathrm{a}$ \\
& 65 & $90.03 \pm 0.35 \mathrm{a}$ & $0.25 \pm 0.01 \mathrm{~d}$ & $15.18 \pm 0.19 \mathrm{~b}$ & $17.33 \pm 0.78 \mathrm{ab}$ \\
\hline
\end{tabular}

Note. Data in this table are expressed as means \pm standard deviations and the data followed by different letters in the same column mean significant differences $(P<0.05)$.

TABLE 2: Effects of drying temperature and relative humidity on TPA characteristics of uncooked CDN.

\begin{tabular}{ccccc}
\hline Temperature $\left({ }^{\circ} \mathrm{C}\right)$ & Relative humidity $(\%)$ & Bending strength $(\mathrm{g})$ & Broken distance $(\mathrm{mm})$ & Broken power $\left(10^{-3} \mathrm{~J}\right)$ \\
\hline \multirow{3}{*}{40} & 65 & $15.21 \pm 0.50 \mathrm{ab}$ & $45.26 \pm 2.26 \mathrm{a}$ & $4.47 \pm 0.10 \mathrm{a}$ \\
& 75 & $13.76 \pm 0.39 \mathrm{c}$ & $35.01 \pm 3.83 \mathrm{~cd}$ & $3.39 \pm 0.31 \mathrm{bc}$ \\
60 & 85 & $14.38 \pm 0.76 \mathrm{bc}$ & $29.10 \pm 2.40 \mathrm{e}$ & $3.01 \pm 0.05 \mathrm{~cd}$ \\
& 65 & $14.67 \pm 0.17 \mathrm{bc}$ & $38.08 \pm 0.84 \mathrm{bc}$ & $3.70 \pm 0.13 \mathrm{~b}$ \\
80 & 75 & $14.41 \pm 0.44 \mathrm{bc}$ & $29.63 \pm 0.75 \mathrm{e}$ & $3.04 \pm 0.20 \mathrm{~cd}$ \\
& 85 & $15.09 \pm 0.31 \mathrm{ab}$ & $31.17 \pm 3.27 \mathrm{de}$ & $3.15 \pm 0.34 \mathrm{~cd}$ \\
& 65 & $14.05 \pm 0.73 \mathrm{c}$ & $32.08 \pm 0.50 \mathrm{de}$ & $2.81 \pm 0.16 \mathrm{~d}$ \\
\hline
\end{tabular}

Note. Data in this table are expressed as means \pm standard deviations and the data followed by different letters in the same column mean significant differences $(P<0.05)$.

and breaking power of CDN firstly decreased and then increased. Under the drying temperature of $40^{\circ} \mathrm{C}$, the breaking distance and breaking power gradually decreased with increasing humidity. Under the combination condition of $40^{\circ} \mathrm{C}$ and $65 \%$, the breaking distance and breaking power were the largest, which were significantly higher than those under other combination conditions $(P<0.05$, Table 2$)$.

Opposite changes of bending strength, broken distance, and broken power were observed between $40^{\circ} \mathrm{C}$ and $80^{\circ} \mathrm{C}$. At $40^{\circ} \mathrm{C}$, the noodle strength was decreased with increasing humidity; in contrast, opposite phenomenon was observed at $80^{\circ} \mathrm{C}$.

\subsection{Quality Properties of Cooked Noodles}

3.2.1. Optimal Cooking Time (OCT). As shown in Table 3, the OCT of dried noodles obtained at drying temperatures of $40^{\circ} \mathrm{C}$ and $60^{\circ} \mathrm{C}$ showed no significant differences between different relative humidities. When the drying temperature was $80^{\circ} \mathrm{C}$, OCT under the relative humidity of $65 \%$ was significantly shorter than that under $75 \%$ and $85 \% P<0.05$, but OCT obtained under relative humidities of $75 \%$ and $85 \%$ showed no significant difference $(P<0.05)$. Under the relative humidity of $65 \%$, OCT obtained at drying temperatures of $60^{\circ} \mathrm{C}$ and $80^{\circ} \mathrm{C}$ was significantly shorter than that at $40^{\circ} \mathrm{C}$, but OCT obtained at drying temperatures of $60^{\circ} \mathrm{C}$ and $80^{\circ} \mathrm{C}$ showed no significant difference. OCT obtained under relative humidities of $75 \%$ and $85 \%$ firstly decreased and then increased with the increase in drying temperature. Under different relative humidities, OCT obtained at the drying temperature of $60^{\circ} \mathrm{C}$ was the shortest.

3.2.2. Water Absorption Ratio (WAR). Temperature and relative humidity had little effect on the WAR of dried noodles. The WAR obtained under the combination condition of $80^{\circ} \mathrm{C}$ and $65 \%$ was the highest, which was significantly higher than that obtained under other combination conditions. The WAR of dried noodles obtained under other combination conditions showed no significant difference (Table 3).

3.2.3. Cooking Loss Ratio (CLR). When the drying temperature was $40^{\circ} \mathrm{C}$, the CLR of dried noodles obtained under different relative humidities showed no significant differences. When the drying temperature was $60^{\circ} \mathrm{C}$, with an increase in the relative humidity, the CLR firstly decreased and then increased. When the drying temperature was $80^{\circ} \mathrm{C}$, the CLR under different relative humidities was the highest (Table 3).

\subsubsection{TPA of Cooked CDN}

(1) Hardness. Table 4 shows the one-way ANOVA results of the effects of drying temperature and relative humidity on the texture characteristics of cooked CDN. When the drying 
TABLE 3: Effects of drying temperature and relative humidity on cooking quality characteristics of CDN.

\begin{tabular}{ccccc}
\hline Temperature $\left({ }^{\circ} \mathrm{C}\right)$ & Relative humidity $(\%)$ & Optimal cooking time (s) & Water absorption ratio (\%) & Cooked loss ratio (\%) \\
\hline \multirow{4}{*}{40} & 65 & $343 \pm 7 \mathrm{a}$ & $162.62 \pm 3.42 \mathrm{~b}$ & $6.86 \pm 0.46 \mathrm{bc}$ \\
& 75 & $337 \pm 6 \mathrm{a}$ & $167.92 \pm 1.54 \mathrm{ab}$ & $6.85 \pm 0.23 \mathrm{bc}$ \\
60 & 85 & $344 \pm 7 \mathrm{a}$ & $164.18 \pm 5.91 \mathrm{~b}$ & $7.00 \pm 0.18 \mathrm{abc}$ \\
& 65 & $314 \pm 10 \mathrm{c}$ & $165.00 \pm 2.41 \mathrm{~b}$ & $6.73 \pm 0.44 \mathrm{~b}$ \\
& 75 & $316 \pm 6 \mathrm{c}$ & $160.00 \pm 2.59 \mathrm{~b}$ & $6.59 \pm 0.51 \mathrm{c}$ \\
80 & 85 & $318 \pm 15 \mathrm{bc}$ & $176.25 \pm 4.30 \mathrm{~b}$ & $7.41 \pm 0.27 \mathrm{ab}$ \\
& 65 & $316 \pm 14 \mathrm{c}$ & $167.65 \pm 3.94 \mathrm{ab}$ & $7.60 \pm 0.49 \mathrm{abc}$ \\
& 75 & $349 \pm 8 \mathrm{a}$ & $158.67 \pm 9.07 \mathrm{~b}$ & $7.17 \mathrm{a}$ \\
\hline
\end{tabular}

Note. Data in this table are expressed as means \pm standard deviations and the data followed by different letters in the same column mean significant differences $(P<0.05)$.

TABLE 4: Effects of drying temperature and relative humidity on TPA of cooked CDN.

\begin{tabular}{|c|c|c|c|c|c|c|c|}
\hline $\begin{array}{l}\text { Temperature } \\
\left({ }^{\circ} \mathrm{C}\right)\end{array}$ & $\begin{array}{c}\text { Relative humidity } \\
(\%)\end{array}$ & Hardness/(g) & Adhesiveness & Springiness & Cohesiveness & Gumminess & Resilience \\
\hline \multirow{3}{*}{40} & 65 & $307.43 \pm 3.94 b$ & $-0.53 \pm 0.08 \mathrm{a}$ & $1.10 \pm 0.03 a$ & $0.67 \pm 0.00 \mathrm{a}$ & $204.84 \pm 2.53 \mathrm{ab}$ & $0.38 \pm 0.01 \mathrm{ab}$ \\
\hline & 75 & $288.20 \pm 1.31 \mathrm{~cd}$ & $-0.73 \pm 0.66 \mathrm{ab}$ & $1.11 \pm 0.00 \mathrm{a}$ & $0.67 \pm 0.01 \mathrm{ab}$ & $191.61 \pm 1.23 \mathrm{~cd}$ & $0.39 \pm 0.01 \mathrm{a}$ \\
\hline & 85 & $289.73 \pm 11.13 \mathrm{~cd}$ & $-0.89 \pm 0.42 \mathrm{ab}$ & $1.05 \pm 0.02 b$ & $0.67 \pm 0.01 \mathrm{a}$ & $193.75 \pm 7.92 \mathrm{bcd}$ & $0.40 \pm 0.01 \mathrm{a}$ \\
\hline \multirow{3}{*}{60} & 65 & $278.02 \pm 4.46 \mathrm{~d}$ & $-4.21 \pm 1.33 c d$ & $1.01 \pm 0.02 b c$ & $0.64 \pm 0.00 \mathrm{e}$ & $178.53 \pm 3.13 \mathrm{e}$ & $0.35 \pm 0.01 d$ \\
\hline & 75 & $289.48 \pm 7.64 \mathrm{~cd}$ & $-3.00 \pm 0.98 \mathrm{bcd}$ & $1.01 \pm 0.01 \mathrm{c}$ & $0.66 \pm 0.01 b c$ & $189.87 \pm 7.36 \mathrm{cde}$ & $0.37 \pm 0.01 b c$ \\
\hline & 85 & $289.67 \pm 8.46 c d$ & $-5.38 \pm 2.06 \mathrm{~d}$ & $1.01 \pm 0.00 c$ & $0.63 \pm 0.00 \mathrm{~d}$ & $182.95 \pm 4.88 \mathrm{de}$ & $0.34 \pm 0.00 \mathrm{e}$ \\
\hline \multirow{3}{*}{80} & 65 & $304.33 \pm 13.35 b c$ & $-4.99 \pm 1.81 \mathrm{~d}$ & $1.02 \pm 0.02 b c$ & $0.64 \pm 0.00 \mathrm{de}$ & $194.16 \pm 8.46 \mathrm{bcd}$ & $0.36 \pm 0.00 \mathrm{~cd}$ \\
\hline & 75 & $307.11 \pm 5.60 \mathrm{~b}$ & $-3.49 \pm 1.36 \mathrm{~cd}$ & $1.02 \pm 0.02 b c$ & $0.64 \pm 0.01 \mathrm{~d}$ & $197.71 \pm 5.71 b c$ & $0.37 \pm 0.01 b$ \\
\hline & 85 & $328.31 \pm 9.74 a$ & $-2.58 \pm 0.22 \mathrm{abc}$ & $1.03 \pm 0.02 b c$ & $0.65 \pm 0.00 \mathrm{~cd}$ & $212.57 \pm 6.12 a$ & $0.38 \pm 0.00 \mathrm{~b}$ \\
\hline
\end{tabular}

Note. Data in this table are expressed as means \pm standard deviations and the data followed by different letters in the same column mean significant differences $(P<0.05)$.

temperature was $40^{\circ} \mathrm{C}$, the noodle hardness obtained under relative humidity of $65 \%$ was significantly higher than that obtained under $75 \%$ and $85 \%$, but the hardness showed no significant difference between $75 \%$ and $85 \%$. When the drying temperature was $60^{\circ} \mathrm{C}$, the hardness under different relative humidities showed no significant difference. When the drying temperature was $80^{\circ} \mathrm{C}$, the hardness obtained under relative humidity of $85 \%$ was significantly higher than $65 \%$ and $75 \%$, but the hardness between $65 \%$ and $75 \%$ showed no significant differences. When the relative humidity was $65 \%$, the hardness of the noodles obtained under the drying temperature of $60^{\circ} \mathrm{C}$ was significantly lower than that obtained under the drying temperatures of $40^{\circ} \mathrm{C}$ and $80^{\circ} \mathrm{C}$, but the hardness of the noodles obtained under drying temperatures of $40^{\circ} \mathrm{C}$ and $80^{\circ} \mathrm{C}$ showed no significant differences. The hardness of dried noodles obtained under the conditions of drying temperature of $80^{\circ} \mathrm{C}$ and the relative humidity of $85 \%$ was the highest. The hardness obtained under the condition of $60^{\circ} \mathrm{C}, 65 \%$ was the lowest.

(2) Adhesiveness. When drying temperatures were, respectively, $40^{\circ} \mathrm{C}$ and $60^{\circ} \mathrm{C}$, the adhesiveness of cooked noodles obtained under different relative humidities showed no significant difference. When the drying temperature was $80^{\circ} \mathrm{C}$, the adhesiveness of noodles decreased with the increase in relative humidity (Table 4 ). When relative humidities were, respectively, $65 \%$ and $75 \%$, the adhesiveness increased with the increase in temperature. When the relative humidity was $85 \%$, the adhesiveness firstly increased and then decreased with the increase in drying temperature.
(3) Springiness. When the drying temperature was $40^{\circ} \mathrm{C}$, the springiness of the cooked noodles under relative humidities of $65 \%$ and $75 \%$ was significantly higher than that under $85 \%$. When drying temperatures were, respectively, $60^{\circ} \mathrm{C}$ and $80^{\circ} \mathrm{C}$, the springiness under different relative humidities showed no significant difference. Under different relative humidities, when the drying temperature increased from $40^{\circ} \mathrm{C}$ to $60^{\circ} \mathrm{C}$, the springiness decreased significantly; when the temperature continued to increase to $80^{\circ} \mathrm{C}$, the springiness showed no significant change (Table 4 ). When the drying temperature was $60^{\circ} \mathrm{C}$, the springiness of the noodles obtained under different relative humidities was the smallest.

(4) Cohesiveness. When drying temperatures were, respectively, $40^{\circ} \mathrm{C}$ and $80^{\circ} \mathrm{C}$, the cohesiveness of cooked noodles under different relative humidities showed no significant difference. But when the drying temperature was $60^{\circ} \mathrm{C}$, the cohesiveness firstly increased and then decreased with the increase in relative humidity. Under different relative humidities, the cohesiveness obtained under $60^{\circ} \mathrm{C}$ and $80^{\circ} \mathrm{C}$ was significantly lower than $40^{\circ} \mathrm{C}$. When the relative humidity was $65 \%$, the cohesiveness under drying temperatures of $60^{\circ} \mathrm{C}$ and $80^{\circ} \mathrm{C}$ showed no significant change. When the relative humidity was $75 \%$, the cohesiveness obtained under $60^{\circ} \mathrm{C}$ was significantly higher than that obtained under $80^{\circ} \mathrm{C}$. When the relative humidity was $85 \%$, the cohesiveness obtained under $60^{\circ} \mathrm{C}$ was significantly lower than that obtained under $80^{\circ} \mathrm{C}$. The cohesiveness obtained under $60^{\circ} \mathrm{C}$ and $85 \%$ was the lowest (Table 4). 
(5) Gumminess. When the drying temperature was $40^{\circ} \mathrm{C}$, the gumminess of the cooked noodles obtained under the relative humidity of $65 \%$ was significantly higher than $75 \%$ and $85 \%$, but gumminess obtained under relative humidities of $75 \%$ and $85 \%$ showed no significant difference. When the drying temperature was $60^{\circ} \mathrm{C}$, gumminess obtained under different relative humidities showed no significant differences. When the drying temperature was $80^{\circ} \mathrm{C}$, the gumminess under $85 \%$ was significantly higher than that under $65 \%$ and $75 \%$, but gumminess obtained under $65 \%$ and $75 \%$ showed no significant difference. Under different relative humidities, the gumminess firstly decreased and then increased with the increase in the drying temperature. The gumminess obtained at the drying temperature of $60^{\circ} \mathrm{C}$ was the lowest. The gumminess obtained under $60^{\circ} \mathrm{C}$ and $65 \%$ was significantly lower than other combination conditions (Table 4).

(6) Resilience. When the drying temperature was $40^{\circ} \mathrm{C}$, the resilience obtained under different relative humidities showed no significant differences. When the drying temperature was $60^{\circ} \mathrm{C}$, the resilience firstly increased and then decreased with the increase in relative humidity. When the drying temperature was $80^{\circ} \mathrm{C}$, the resilience under the relative humidity of $65 \%$ was significantly lower than that under $75 \%$ and $85 \%$, but the resilience obtained under $75 \%$ and $85 \%$ showed no significant difference. Under different relative humidities, the resilience obtained at the drying temperature of $40^{\circ} \mathrm{C}$ was significantly higher than that under $60^{\circ} \mathrm{C}$ and $80^{\circ} \mathrm{C}$. When relative humidities were $65 \%$ and $75 \%$, the resilience at drying temperatures of $60^{\circ} \mathrm{C}$ and $80^{\circ} \mathrm{C}$ showed no significant difference. Under the relative humidity of $85 \%$, the resilience obtained at $60^{\circ} \mathrm{C}$ was significantly lower than that $80^{\circ} \mathrm{C}$. The resilience obtained under $60^{\circ} \mathrm{C}$ and $85 \%$ was significantly lower than that of other combination conditions.

\subsection{Images of Scanning Electron Microscopy (SEM).} Figure 1 shows SEM images of noodles cross sections prepared under different conditions of drying temperature and relative humidity. Figures 1(a) and 1(b) are, respectively, images of 300X magnification and 1000x magnification. Dried noodles had a dense internal structure and the gluten network formed a continuous sheet structure, where large and small starch granules were tightly adhered or wrapped. The surface of partial starch granules shrank. The binding capacity between starch granules and gluten inside dried noodles obtained under different conditions of drying temperature and relative humidity showed the significant differences and starch granules fell away at the cross section of dried noodles to different degrees. In the noodles obtained at the drying temperature of $80^{\circ} \mathrm{C}$, the falling phenomenon of starch granules was the most serious. The binding between starch granules and gluten network structure is related to bending strength, water absorption ratio, and cooking loss ratio of the noodles.

3.4. Fourier Transform Infrared (FTIR) Microscopy. The protein quantity distribution diagrams at the cross section and surface of the noodles produced under different conditions are shown in Figure 2. The protein quantity distribution at the cross section of the noodles was largely affected by drying temperature (Figure 2(a)). Especially at the drying temperature of $80^{\circ} \mathrm{C}$, the protein aggregation was serious, and the aggregation phenomenon was more significant at the cross section. The falling phenomenon of starch granules observed by SEM may be related to protein aggregation.

Compared with cross section (Figure 2(a)), the protein distribution on the surface of noodles (Figure 2(b)) showed the decreased uniformity. Under the conditions of $80^{\circ} \mathrm{C}$ and $75 \%$, the protein distribution on the noodle surface showed the worst uniformity and the obvious protein aggregation was observed. Protein aggregation may reduce its ability to wrap starch granules. Therefore, starch granules on the surface tended to fall off during cooking and the cooking loss ratio increased. The results were consistent with the variations of cooking loss ratio with drying temperature and relative humidity.

\section{Discussion}

Temperature and relative humidity are the main control factors in the drying process of noodles and affect the drying efficiency and quality of noodles [3-6]. At present, the common production process of noodles in China is the hot air convection drying process at medium temperature $\left(\leq 45^{\circ} \mathrm{C}\right)$ [3]. Since 1970 s and 1980 s, the high-temperature drying process had been explored in the production of spaghetti in Italy and Japanese dried noodles and was widely applied in the production of spaghetti. Higher drying temperatures $\left(>60^{\circ} \mathrm{C}\right)$ could improve the cooking characteristics of spaghetti $[10,11]$. This study indicated that drying temperature and relative humidity had significant or extremely significant effects on the color, density, shrinkage, cooking characteristics, and texture characteristics of dried noodles. However, the influences on various indicators of dried noodles were different. The drying temperature had a great influence on OCT and TPA characteristics of $\mathrm{CDN}$. The relative humidity had great effects on the $\mathrm{L}^{*}$ value, $\mathrm{a}^{*}$ value, and bending strength of $\mathrm{CDN}$. In general, when the drying temperature was $60^{\circ} \mathrm{C}$, OCT, hardness, cohesiveness, gumminess, chewiness, and resilience reduce, and the cooking characteristics of CDN can improve to a certain degree. This study confirmed that the quality of noodle products could be adjusted by regulating different combinations of drying temperature and relative humidity.

Bruneel et al. pointed out that the formation of a suitable protein network structure during drying largely determined the quality of spaghetti produced from durum wheat [12]. Verbauwhede et al. observed the changed microstructure of the gluten protein network, cleaved hydrogen bonds, protein recombination caused by hydrophobic interactions, and branched protein structure when nonfermented dough was heated above $65^{\circ} \mathrm{C}$ [13]. In this study, the SEM and FTIR results indicated that, with the increase in temperature, the internal microstructure or protein content distribution of dried noodles showed significant change. When the drying temperature increased to $60^{\circ} \mathrm{C}$, due to protein aggregation, 

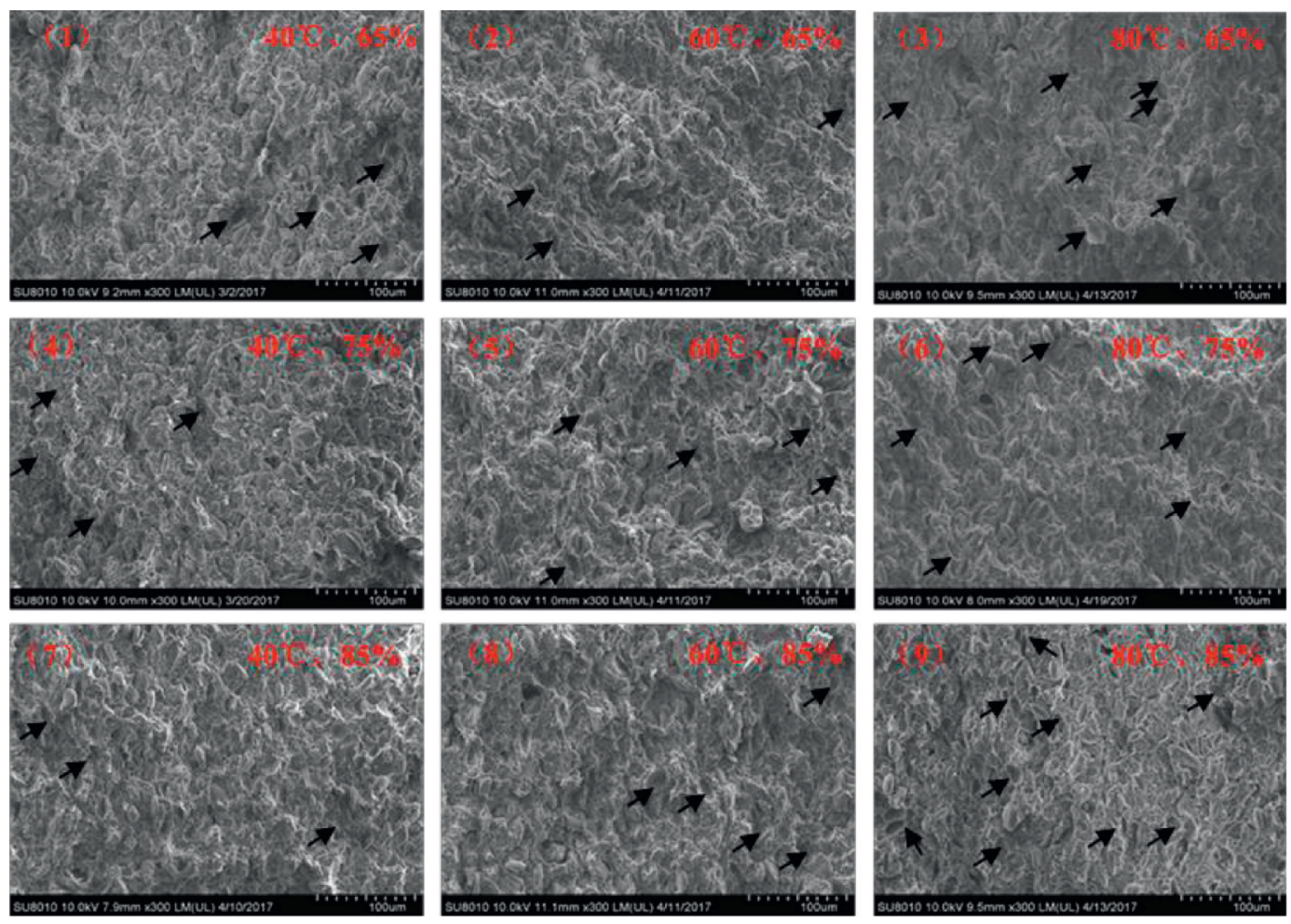

(a)
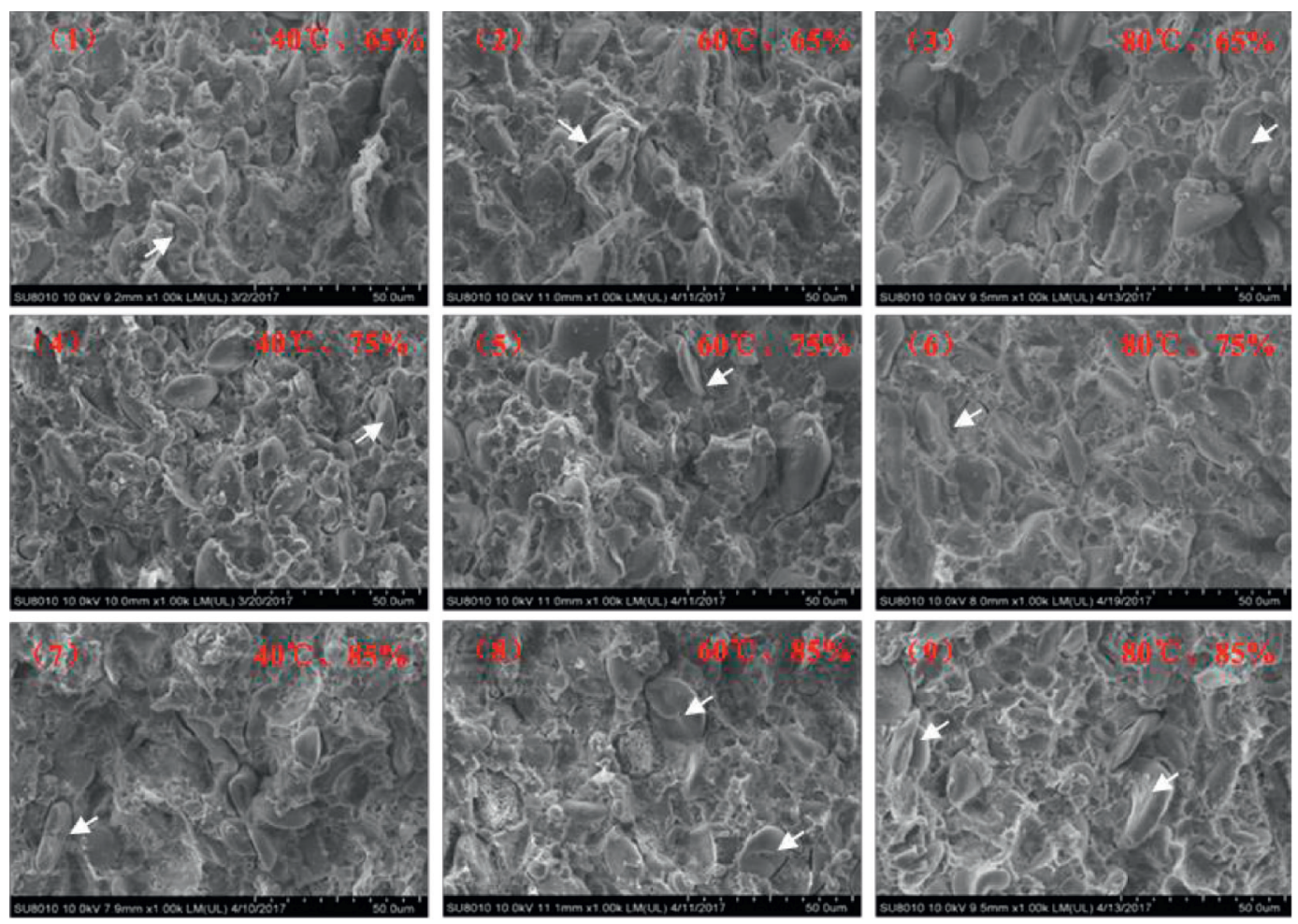

(b)

FIgURE 1: SEM of cross sections of CDN at different drying temperatures and relative humidities ((a) $\times 300$; (b) $\times 1000)$. 

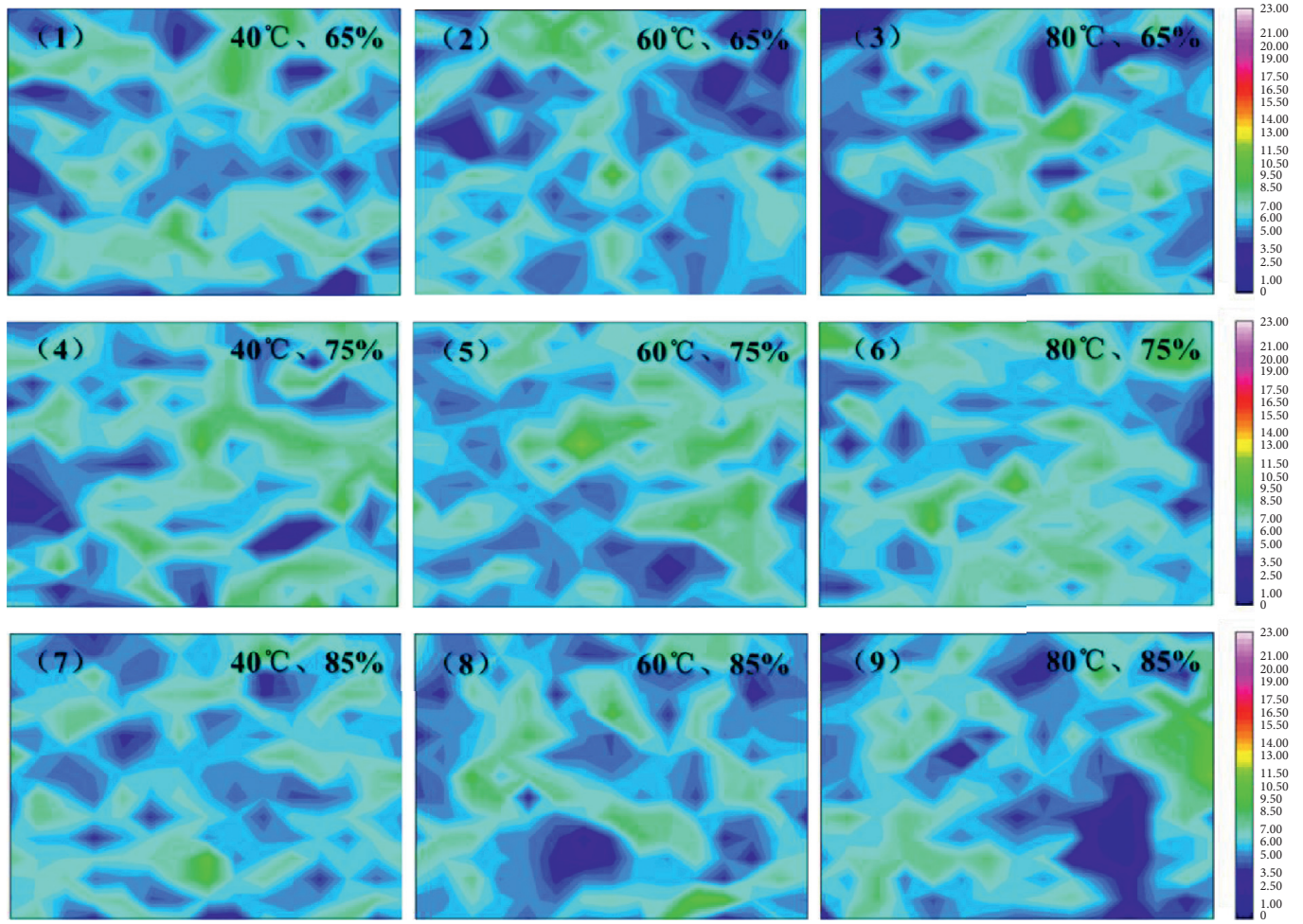

(a)
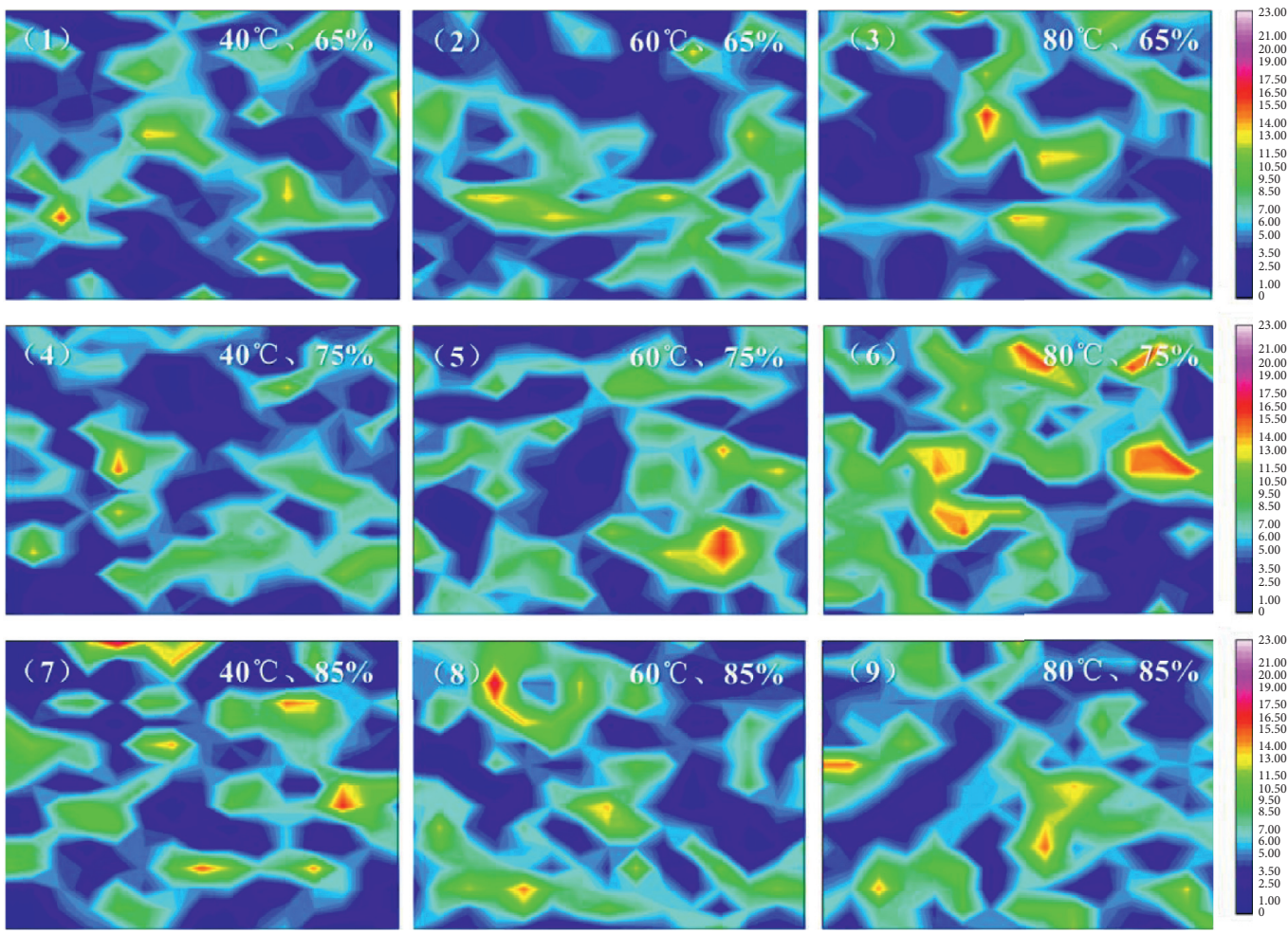

(b)

Figure 2: Contour plots of the variation of protein quantity for cross sections (a) and surfaces (b) of dried noodles at different drying temperatures and relative humidities. 
the surface protein distribution became uneven and starch swelling was not observed.

\section{Conclusions}

Drying temperature and relative humidity have significant effects on quality characteristics of CDN. However, the influences on different indicators were different. Drying temperature was the main influencing factor of the quality of $\mathrm{CDN}$ and protein microstructure. After the drying temperature exceeded $60^{\circ} \mathrm{C}$, proteins began to aggregate, and the surface protein distribution became uneven. A high temperature $\left(60^{\circ} \mathrm{C}\right)$ could improve the quality of $\mathrm{CDN}$ products. The quality of $\mathrm{CDN}$ products could be adjusted by the combination of drying temperature and relative humidity. But in the practical application process, the adjustment should be considered based on the performance of drying equipment, production targets, energy consumption requirements, and drying process parameters.

\section{Data Availability}

The data used to support the findings of this study are included within the article.

\section{Conflicts of Interest}

The authors declare that they have no conflicts of interest.

\section{Acknowledgments}

The study was funded by the National Key Research and Development Plan (2016YFD0400200), the National Natural Science Foundation of China (no. 31501527), and Chinese Agricultural Research System (CARS-03).

\section{References}

[1] R. Liu, V. A. Solah, Y. Wei et al., "Sensory evaluation of Chinese white salted noodles and steamed bread made with Australian and Chinese wheat flour," Cereal Chemistry, vol. 96, no. 1, pp. 66-75, 2019.

[2] Y. Wei, Y. Zhang, R. Liu, B. Zhang, M. Li, and S. Jin, "Origin and evolution of Chinese noodles," Cereal Foods World, vol. 62, no. 2, pp. 44-51, 2017.

[3] J. Y. Wang, J. Y. Liu, R. Z. Wang, and L. W. Wang, "Experimental research of composite solid sorbents for fresh water production driven by solar energy," Applied Thermal Engineering, vol. 121, pp. 941-950, 2017.

[4] B. X. Fu, "Asian noodles: history, classification, raw materials, and processing," Food Research International, vol. 41, no. 9, pp. 888-902, 2008.

[5] T. Inazu and K. Iwasaki, "Mathematical evaluation of effective moisture diffusivity in fresh Japanese noodles (udon) by regular regime theory," Journal of Food Science, vol. 65, no. 3, pp. $440-444,2000$.

[6] T. Inazu, K.-I. Iwasaki, T. Furuta et al., "Effect of temperature and relative humidity on drying kinetics of fresh Japanese noodle (Udon)," LWT-Food Science and Technology, vol. 35, no. 8, pp. 649-655, 2002.

[7] J. De Temmerman, P. Verboven, B. Nicola1", and H. Ramon, "Modelling of transient moisture concentration of semolina pasta during air drying," Journal of Food Engineering, vol. 80, no. 3, pp. 892-903, 2007.

[8] S. Villeneuve and P. Gélinas, "Drying kinetics of whole durum wheat pasta according to temperature and relative humidity," LWT-Food Science and Technology, vol. 40, no. 3, pp. 465-471, 2007.

[9] T. Ogawa, T. Kobayashi, S. Adachi et al., "Prediction of pasta drying process based on a thermogravimetric analysis," Journal of Food Engineering, vol. 111, no. 1, pp. 129-134, 2012.

[10] S. Mercier, C. Moresoli, M. Mondor, S. Villeneuve, and B. Marcos, "A meta-analysis of enriched pasta: what are the effects of enrichment and process specifications on the quality attributes of pasta?" Comprehensive Reviews in Food Science and Food Safety, vol. 15, no. 4, pp. 685-704, 2016.

[11] L. Padalino, R. Caliandro, G. Chita, A. Conte, and M. A. Del Nobile, "Study of drying process on starch structural properties and their effect on semolina pasta sensory quality," Carbohydrate Polymers, vol. 153, pp. 229-235, 2016.

[12] A. K. Anderson and P. K. W. Ng, "Changes in disulfide and sulfhydryl contents and electrophoretic patterns of extruded wheat flour proteins," Cereal Chemistry Journal, vol. 77, no. 3, pp. 354-359, 2000.

[13] C. S. Park, B. H. Hong, and B.-K. Baik, "Protein quality of wheat desirable for making fresh white salted noodles and its influences on processing and texture of noodles," Cereal Chemistry Journal, vol. 80, no. 3, pp. 297-303, 2003.

[14] C. Bruneel, B. Pareyt, K. Brijs, and J. A. Delcour, "The impact of the protein network on the pasting and cooking properties of dry pasta products," Food Chemistry, vol. 120, no. 2, pp. 371-378, 2010.

[15] A. E. Verbauwhede, M. A. Lambrecht, M. Jekle et al., "Microscopic investigation of the formation of a thermoset wheat gluten network in a model system relevant for bread making," International Journal of Food Science \& Technology, vol. 55, no. 2, pp. 891-898, 2020.

[16] Z. Wang, X. Yu, Y. Zhang, B. Zhang, M. Zhang, and Y. Wei, "Effects of gluten and moisture content on water mobility during the drying process for Chinese dried noodles," Drying Technology, vol. 37, no. 6, pp. 759-769, 2019.

[17] X. Yu, Z. Wang, Y. Zhang, S. A. Wadood, and Y. Wei, "Study on the water state and distribution of Chinese dried noodles during the drying process," Journal of Food Engineering, vol. 233, pp. 81-87, 2018.

[18] AACC, "Approved methods of the American association of cereal chemistry," Methods, vol. 66-50, 2000.

[19] R. Liu, Y.-M. Wei, Y.-N. Xing, J. Wang, Y.-Q. Zhang, and B. Zhang, "Sensory quality and physico-chemical properties of three types of commercial dried Chinese noodles," Advance Journal of Food Science and Technology, vol. 10, no. 4, pp. 262-269, 2016.

[20] R. Liu, Y. Zhang, B. Zhang, J. Ban, and Y. Wei, "Influence of vacuum mixing on structural characteristics and physical properties of noodle dough," Cereal Chemistry Journal, vol. 93, no. 3, pp. 226-233, 2016.

[21] R. Wang, M. Li, S. Chen, Y. Hui, A. Tang, and Y. Wei, "Effects of flour dynamic viscosity on the quality properties of buckwheat noodles," Carbohydrate Polymers, vol. 207, pp. 815-823, 2019. 